\title{
PERANCANGAN MEDIA PEMBELAJARAN ALAT MUSIK PIANIKA MENGGUNAKAN GREENFOOT
}

\author{
Eggy Listya Sutigno ${ }^{1)}$, Oky Dwi Nurhayati ${ }^{2)}$, Kurniawan Teguh Martono ${ }^{2)}$ \\ Program Studi Sistem Komputer, Fakultas Teknik, Universitas Diponegoro \\ Jln. Prof. Sudharto, Tembalang, Semarang, Indonesia \\ Email: eggylistyasutigno@gmail.com
}

\begin{abstract}
Abstrak - Kemajuan teknologi yang pesat saat ini, dapat memudahkan seseorang untuk menghafal sesuatu yang baru dengan cara yang menarik terutama yang berbasis komputer.Salah satu nya adalah media pembelajaran alat musik pianika.Media pembelajaran alat musik pianika berbasis komputer ini sangat digemari oleh anak-anak bahkan orang dewasa karena menarik, menghibur, dan menstimulasi kelincahan intelektual. Selain dapat menghilangkan kejenuhan, media pembelajaran alat musik pianika juga merupakan salah satu cara efektif untuk mengenalkan kepada anak lagu wajib nasional.

Media pembelajaran alat musik pianika untuk mempermudah pembelajaran ini dirancang menggunakan perangkat lunak Greenfoot, yang mendukung bahasa pemrograman Java secara utuh. Greenfoot juga dilengkapi dengan perangkat bantu seperti class browser, editor, dan compiler, yang membuat konsep pemrograman berorientasi objek pada Greenfoot menjadi lebih mudah dimengerti. Media pembelajaran alat musik pianika ini dapat dimainkan oleh semua jenis kelamin dengan target pengguna di atas 7 tahun. Hasil dari perancangan aplikasi ini yaitu terealisasinya media pembelajaran alat musik pianika untuk memudahkan pembelajaran pengenalan lagu wajib. Harapannya, media pembelajaran alat musik pianika ini tidak hanya dapat digunakan sebagai media untuk pembelajaran tetapi juga menjadi hiburan yang bermakna dan bermanfaat.
\end{abstract}

Kata Kunci : Musik, Elektronik, Pembelajaran, Greenfoot

\section{PENDAHULUAN}

Seiring perkembangan zaman, pemanfaatan teknologi untuk berbagai kepentingan di Indonesia terus berkembang. Perkembangan teknologi informasi dapat meningkatkan kinerja dan memungkinkan berbagai kegiatan dilaksanakan dengan cepat, tepat, dan akurat sehingga pada akhirnya dapat meningkatkan produktivitas. Perkembangan teknologi informasi sekarang ini memunculkan berbagai jenis kegiatan berbasis pada teknologi ini, termasuk dalam bidang pendidikan.

Tujuan dari penelitian ini adalah merancang media pembelajaran alat musik pianika yang dapat digunakan sebagai alternatif pembelajaran tanpa harus memiliki alat musik pianika dengan tampilan yang lebih interaktif menggunakan greenfoot dan mengenalkan lagu wajib nasional melalui instrumen alat musik pianika untuk semua jenis kelamin dari umur 7 tahun ke atas

Dengan perkembangan teknologi tersebut maka memungkinkan banyak cara pembelajaran yang interaktif menggunakan media yang sekarang tersedia. Salah satunya adalah media pembelajaran alat musik pianika. Media pembelajaran alat musik pianika dapat dibuat menggunakan berbagai macam perangkat lunak seperti Game Maker, Adventure Maker, 3D Game Studio, Greenfoot dan lain-lain.

Media pembelajaran alat musik pianika ini diharapkan tidak hanya dapat mengisi waktu luang saja, tetapi dapat mempermudah anak menghafal berbagai lagu wajib dan memainkan nada lagu wajib tersebut menggunakan media pembelajaran alat musik yang menyerupai pianika.

\section{DASAR TEORI}

\subsection{Media Pembelajaran}

Kata media berasal dari bahas Latin medius yang secara harfiah berarti tengah, perantara atau pengantar. Association of Education and Communication Technology (AECT) memberikan definisi media sebagai sistem transmisi (bahan dan peralatan) yang tersedia untuk menyampaikan pesan tertentu. Secara lebih khusus media bisa disebut sebagai sarana fisik untuk menyampaikan isi atau materi pembelajaran. Dengan demikian televisi, film, foto, rekaman audio, gambar yang diproyeksikan, bahan-bahan cetakan, dan sejenisnya adalah tergolong media.

Media pembelajaran dapat dikatakan sebagai alatalat grafis, photografis, atau elektronis, yang dapat digunakan untuk menangkap, memproses, dan menyusun kembali informasi visual atau verbal. Media merupakan komponen sumber belajar atau wahana fisik yang mengandung materi instruksional di lingkungan siswa yang dapat merangsang siswa untuk belajar.

\subsection{Multimedia}

Multimedia adalah pemanfaatan komputer untuk membuat dan menggabungkan beberapa media seperti teks, grafik, suara, dan gambar gerak (animasi dan video) dengan menggabungkan tautan dan perangkat yang memungkinkan pemakai melakukan navigasi, berinteraksi, dan berkomunikasi.

Di dalam multimedia, terkandung beberapa media seperti teks, suara, video, gambar, dan animasi. Di bawah 
ini dijelaskan mengenai objek-objek yang terdapat dalam multimedia.

1. Teks

Teks dapat berupa kata atau narasi dalam multimedia yang menyajikan bahasa. Kebutuhan teks tergantung pada kegunaan aplikasi multimedia.

2. Grafik (Image)

Grafik menjadi nilai dan unsur tambah suatu penyajian data. Gambar digunakan dalam presentasi multimedia untuk menarik perhatian dan dapat mengurangi kebosanan, apabila dibandingkan dengan teks.

3. Suara (Audio)

Penyampaian sebuah informasi yang sering disertai desain grafis dan teks yang menarik, akan terasa hampa dan membosankan apabila tidak disertai dengan suara di dalamnya. Diperlukan narasi atau suara yang menyertai dan menjelaskan informasi yang disampaikan agar lebih mudah dipahami.

4. Video

Video akan membuat aplikasi multimedia lebih hidup. Namun kendala yang dihadapi dalam memanfaatkan media ini adalah ukuran berkas yang terlalu besar.

5. Animasi

Multimedia animasi merupakan penggunaan komputer untuk menciptakan gerak .

\subsection{Bahasa Pemrograman Java}

Java merupakan bahasa pemrograman yang dapat dijalankan di berbagai komputer termasuk telepon genggam. Bahasa ini banyak mengadopsi sintaksis yang terdapat pada $\mathrm{C}$ dan $\mathrm{C}++$, namun dengan sintaksis model objek yang lebih sederhana serta dukungan rutin-rutin aras bawah yang minimal. Java memperkenalkan diri sebagai bahasa pemrograman yang mendukung konsep

Object Oriented Programming (OOP) secara total. Maksudnya adalah bahwa sejak awal mula Java diciptakan, Java memang dibuat untuk mendukung konsep OOP tersebut. Oleh karena itu, struktur bahasa pemrograman Java harus memiliki sebuah kelas utama dan sebuah metode utama (main method).

Semboyan utama Java yang terkenal adalah Write Once Run Everywhere. Maksudnya cukup dengan menuliskan kode sumber sekali saja pada sebuah komputer, maka akan dapat menjalankannya pada komputer lain yang memiliki JVM (Java Virtual Machine). Hal ini dapat melambangkan portabilitas Java yang sangat mudah dilakukan

\subsection{Greenfoot}

Greenfoot merupakan perangkat lunak yang

dirancang untuk pemula yang ingin mendapatkan pengalaman baru dengan pemrograman berorientasi objek. Perangkat lunak ini didukung dengan aplikasi grafis berbasis pemrograman Java. Selain berbentuk teks seperti editor lainnya, pada Greenfoot ini terdapat perangkat bantu seperti class browser, editor dan compiler. Greenfoot juga mendukung bahasa Java secara utuh. Dengan adanya bantuan perangkat-perangkat tersebut, konsep pemrograman berorientasi objek pada Greenfoot menjadi lebih mudah dimengerti.

Di dalam Greenfoot terdapat project yang disebut Scenario. Di dalam project tersebut, kita dapat membuat kelas. Dengan menambahkan sebuah kelas pada Scenario, maka akan dapat meletakkan tipe objek atau instansiasi dari kelas ke dalam Scenario.

Terdapat dua macam tipe kelas dari pustaka Greenfoot, yaitu kelas World dan Actor. World merupakan latar dari permainan yang akan dibuat, sedangkan kelas Actor adalah sebuah kelas yang berfungsi sebagai karakter pada permainan yang akan dibuat.

\section{PERANCANGAN SISTEM}

Sebuah media pembelajaran akan terlihat bagus apabila konsep dan grafik yang disajikan juga terlihat bagus. Dalam pengembangan media pembelajaran diperlukan struktur skenario cerita yang jelas dan tampilan yang dapat menarik minat penggunanya, maka dari itu perlu disusun tahap pengembangan dengan urutan yang jelas untuk mendapatkan hasil yang maksimal. Langkah-langkah penelitian sistem secara umum akan digambarkan menggunakan diagram alir atau flowchart. Gambar 1 menunjukkan diagram alir dari langkahlangkah penelitian secara umum

Pada perancangan ini, metode yang digunakan adalah metode waterfall. Metode waterfall merupakan metode yang sering digunakan oleh penganalisa sistem pada umumnya. Inti dari metode waterfall adalah pengerjaan dari suatu sistem dilakukan secara berurutan atau secara linear. Jadi jika langkah analisa belum dikerjakan, maka langkah design sistem tidak dapat dikerjakan. Jika langkah design sistem belum dikerjakan maka seterusnya tidak dapat dikerjakan

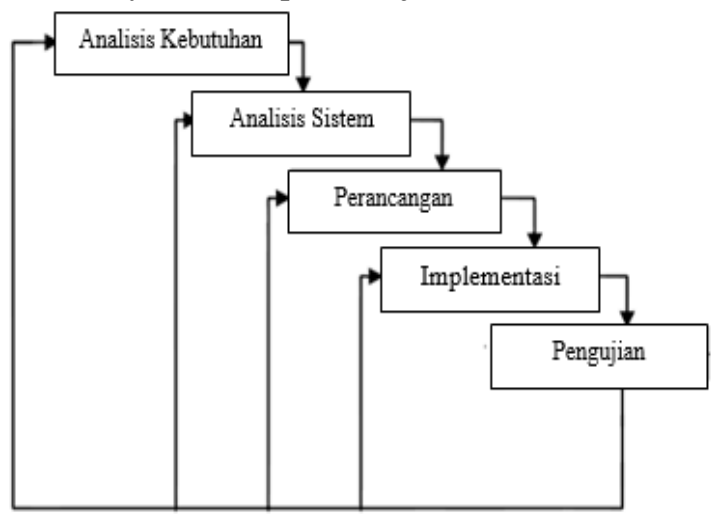

3.1 Analisa Kebutuhan

Konsep dasar dari media pembelajaran ini yaitu menarik dan mudah dimainkan. Perpaduan unsur teks, suara, dan gambar juga berpengaruh dalam media pembelajaran ini, karena media inilah yang akan memberikan rasa ketertarikan pada anak-anak. Media pembelajaran alat musik pianika dimainkan dengan cara menekan tuts dimana setiap tuts akan mengeluarkan nada yang berbeda.

Pada halaman awal akan ada beberapa tombol 
diantara nya tombol Mengenal Nada, Indonesia Raya, Ibu Kita Kartini, Mengheningkan Cipta, Satu Nusa Satu Bangsa, Bagimu Negri, dan tombol Bantuan. Jika menekan tombol Mengenal Nada maka ada tampilan pianika dimana jika diteka tutsnya akan menghasilkan nada yang diinginkan. Apabila menekan button Indonesia Raya, Ibu Kita Kartini, Mengheningkan Cipta, Satu Nusa Satu Bangsa, Bagimu Negri maka ada tampilan pianika yang bisa dimainkan dan ada tutorial lagu sesuai nama tombol yang ditekan. Kemudian pada tombol Bantuan merupakan keterangan bagaimana cara menggunakan media pembelajaran alat musik pianika ini.

\subsubsection{Kebutuhan Fungsional}

Skenario dari Media Pembelajaran Alat Musik Pianika ini yaitu sbb

1. Media pembelajaran alat musik pianika pada halaman awal memiliki beberapa tombol diantaranya Mengenal Nada, tombol lagu dimana terdapat 5 lagu, serta tombol Bantuan..

2. Ketika tombol Mengenal Nada ditekan maka akan muncul tampilan pianika dimana ada beberapa tuts berwarna putih dan hitam. Apabila ditekan dengan cara di klik atau menekan beberapa huruf di keyboard maka tuts tersebut akan menghasilkan beberapa nada seperti ketika memainkan alat musik pianika. Kemudian pada halaman ini terdapat tombol kembali yang bila ditekan maka tampilan akan kembali pada halaman awal.

3. Ketika tombol lagu misal Indonesia Raya ditekan maka akan muncul tampilan pianika. Pianika tersebut akan memberikan tutorial bagaimana dan tuts apa saja yang harus ditekan ketika untuk dapat menghasilkan nada Indonesia Raya. Begitu juga dengan button lagu lain Ibu Kita Kartini, Mengheningkan Cipta, Satu Nusa Satu Bangsa, Bagimu Negri.

4. Video

Kemudian tombol terakhir tombol Bantuan yang apabila ditekan akan menuju ke halaman dimana pada halaman tersebut berisi tata cara menggunakan media pembelajaran alat musik pianika

\subsubsection{Kebutuhan Non Fungsional}

1. Media pembelajaran alat musik pianika ini dapat berjalan pada sistem operasi windows.

2. Media pembelajaran ini dapat dijalankan dengan file .jar

\subsection{Tahap Perencanaan}

\subsubsection{Merancang Grafik}

Berikut merupakan gambar rancangan antarmuka pengguna pada "Media pembelajaran alat musik pianika".

1. Rancangan Halaman Awal

Gambar 2 menunjukkan rancangan halaman awal media pembelajaran alat musik pianika yang akan dibuat.

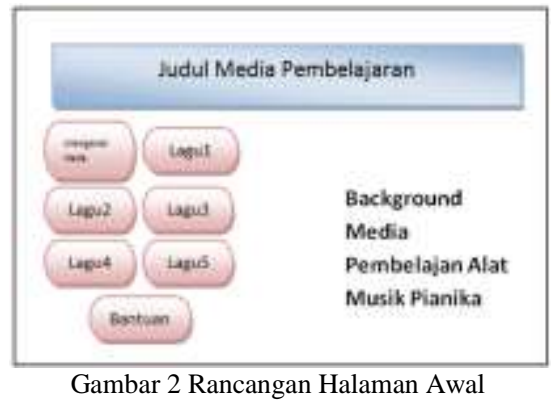

2. Rancangan Petunjuk Media pembelajaran alat musik pianika

Gambar 3 menunjukkan tampilan halaman petunjuk media pembelajaran alat musik pianika.

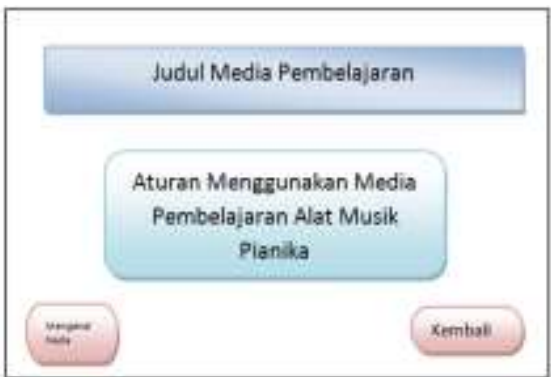

Gambar 3 Rancangan Halaman Petunjuk Media Pembelajaran Alat Musik Pianika

3. Rancangan Papan Mengenal Nada

Gambar 4 menunjukkan rancangan gambar alat musik pianika yang dapat dijadikan simulasi pembelajaran memainkan alat musik.

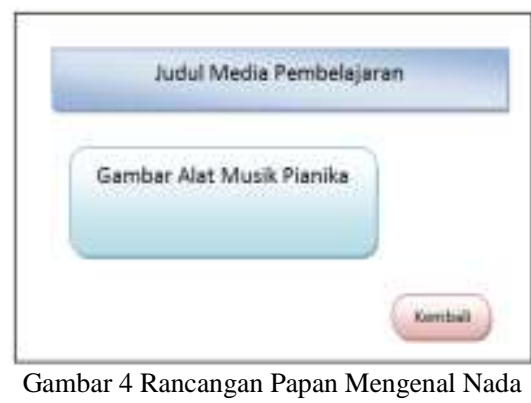

4. Rancangan Papan Lagu

Gambar 5 menunjukkan rancangan tampilan Papan Lagu dalam media pembelajaran alat musik pianika ini.

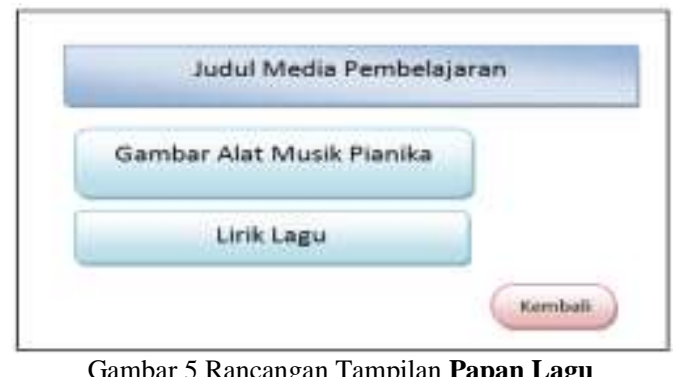




\subsubsection{Merancang Grafik}

Berikut merupakan gambar rancangan antarmuka pengguna pada "Media pembelajaran alat musik pianika".

\subsubsection{Diagram Use Case}

Diagram ini menggambarkan interaksi antara pengguna dengan sistem, dalam hal ini yaitu pemain dan media pembelajaran alat musik pianika yang dimainkan. Diagram use case dalam media pembelajaran alat musik pianika ini dapat dilihat pada Gambar 6.

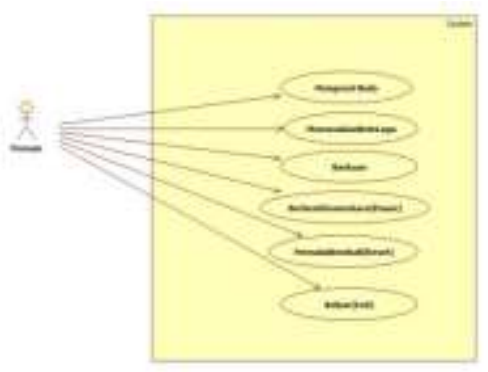

Gambar 6. Diagram Use Case pada Media Pembelajaran Alat Musik Pianika

\subsubsection{Diagram Use Case}

Terdapat 10 use case pada diagram use case, sehingga penggambaran diagram sequence juga mengikuti jumlah use case dalam diagram use case.

1. Diagram Sequence untuk Use Case Mengenal Nada Diagram Sequence untuk use case Mengenal Nada dapat dilihat pada Gambar 7.

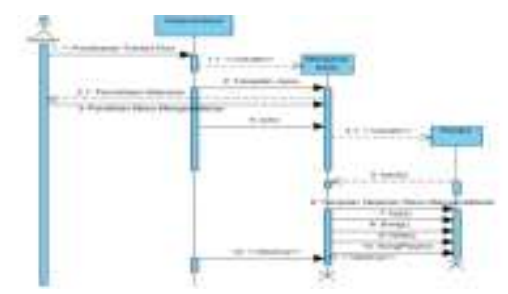

Gambar 7. Diagram Sequence untuk Use Case Mengenal Nada

2. Diagram Sequence untuk Use Case Memasukan Note Lagu

Diagram Sequence untuk use case Memasukan Note Lagu dapat dilihat pada Gambar 8.

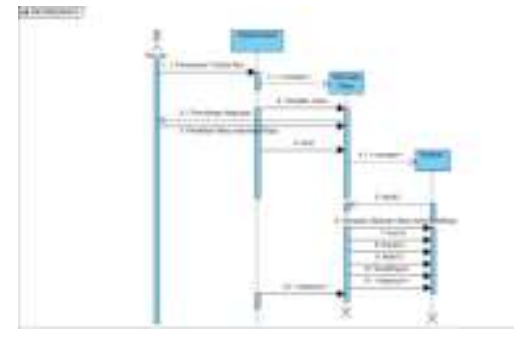

Gambar 8 Diagram Sequence untuk Use Case Indonesia Raya
3. Diagram Sequence untuk Use Case Bantuan

Diagram Sequence untuk use case Bantuan dapat dilihat pada Gambar 9.

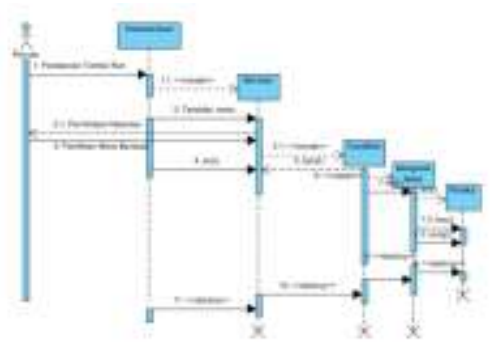

Gambar 9. Diagram Sequence untuk Use Case Bantuan

4. Diagram Sequence untuk Use Case Pause

Diagram Sequence untuk use case Pause dapat dilihat pada Gambar 10.

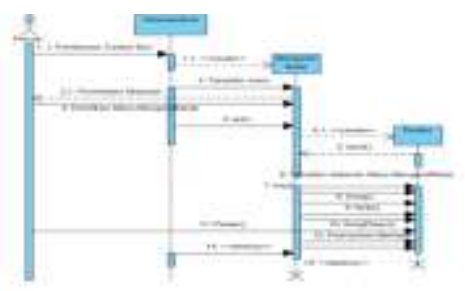

Gambar 10. Diagram Sequence untuk Use Case

BerhentiSementara (Pause)

5. Diagram Sequence untuk Use Case Reset

Diagram Sequence untuk use case Reset dapat dilihat pada Gambar 11.

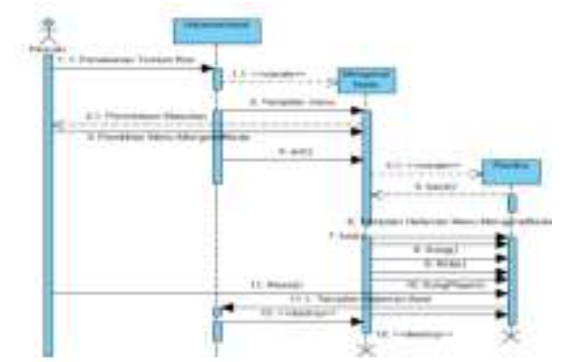

Gambar 11. Diagram Sequence untuk Use Case

MemulaiKembali (Reset)

6. Diagram Sequence untuk Use Case Pause

Diagram Sequence untuk use case Pause dapat dilihat pada Gambar 12.

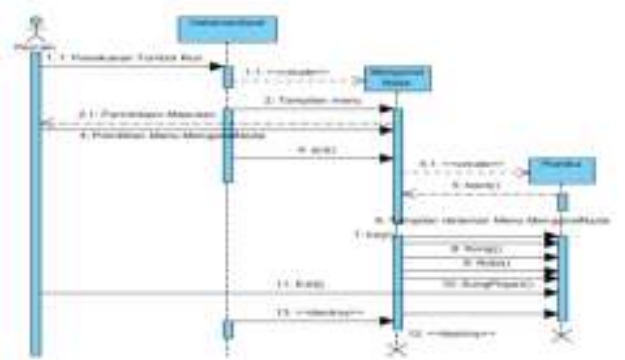

Gambar 12. Diagram Sequence untuk Use Case Keluar(Exit) 


\subsubsection{Diagram Kelas}

Berikut adalah diagram kelas dari superkelas World. Gambar 13 Menunjukkan diagram kelas dari superkelas World

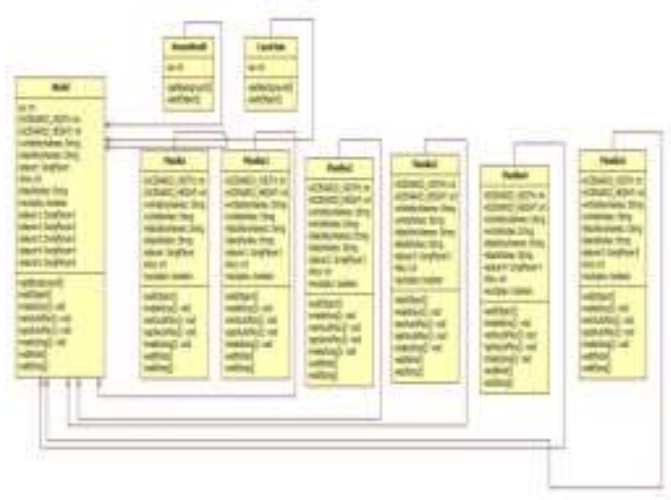

Gambar 13 Diagram Kelas pada superkelas World

Kemudian gambar dibawah adalah diagram kelas dari superkelas Actor. Gambar 14 Menunjukkan diagram kelas dari superkelas Actor.

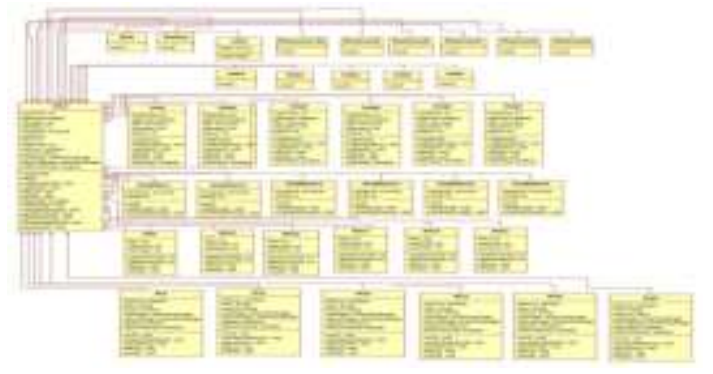

Gambar 14 Diagram Kelas pada superkelas Actor

\section{IMPLEMENTASI DAN PENGUJIAN SISTEM}

4.1 Implementasi Program

1. Objek key

Objek key merupakan objek utama karena ada pada setiap menu media pembelajaran alat musik pianika. Gambar 15 menunjukan objek key yang ada pada media pembelajaran alat musik pianika

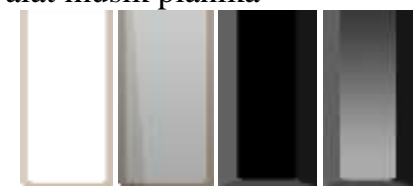

Gambar 15 Tampilan Objek Key

\section{Objek Tombol Navigator}

Gambar 16 menunjukkan tombol navigator yang terdapat Media Pembelajaran Alat Musik Pianika.

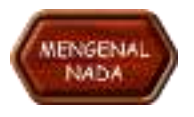

(a)

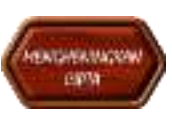

(d)

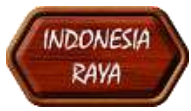

IBU KITA

KARTINI

(b)

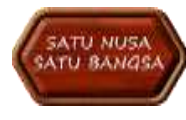

BAGIMU

NEGERI

(e)

(f) (c)

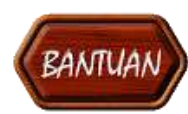

(g)

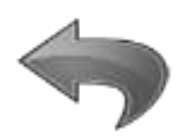

(h)
Gambar 16 Tampilan Tombol Navigator

(a) Tombol Mengenal Nada; (b) Tombol Indonesia Raya; (c) Tombol Ibu Kita Kartini Tombol Mengheningkan Cipta; (d) Tombol Satu Nusa Satu Bangsa; (e) Tombol Bagimu Negri Tombol Bantuan; (f) Tombol Kembali

3. Tampilan Halaman Awal

Tampilan halaman awal media pembelajaran alat musik pianika tampak seperti pada Gambar 17.

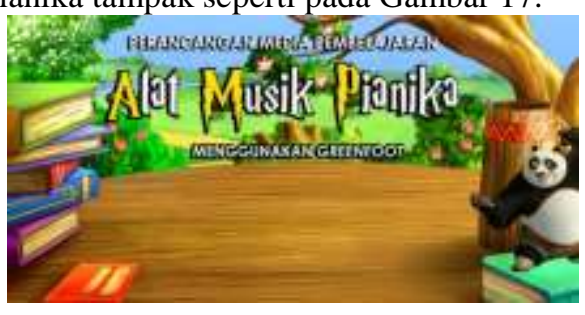

Gambar 17 Tampilan Halaman Awal

4. Tampilan Petunjuk Permainan

Gambar 18 menunjukkan tampilan halaman petunjuk permainan, disertai dengan tombol Mengenal Nada dan Kembali.

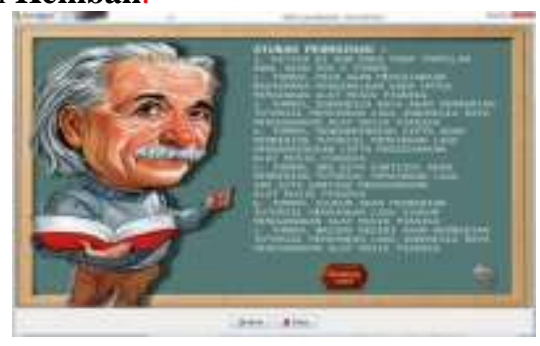

Gambar 18 Tampilan Petunjuk Permainan

5. Tampilan Papan Halaman Mengenal Nada

Tampilan halaman main media pembelajaran alat musik pianika tampak seperti pada Gambar 19.

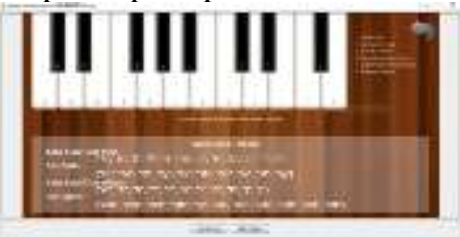

Gambar 19 Tampilan Halaman Mengenal Nada 
6. Tampilan Halaman Indonesia Raya

Tampilan halaman Indonesia Raya media pembelajaran alat musik pianika tampak seperti pada Gambar 20.

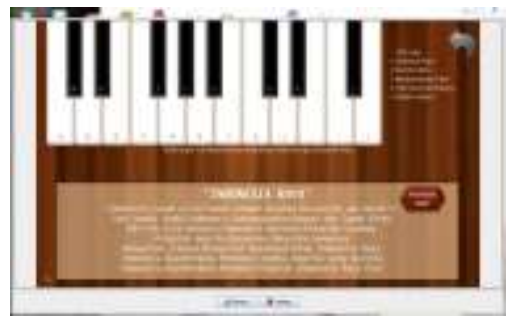

Gambar 20 Tampilan Halaman Indonesia Raya

7. Tampilan Halaman Ibu Kita Kartini

Tampilan halaman Indonesia Raya media pembelajaran alat musik pianika tampak seperti pada Gambar 21.

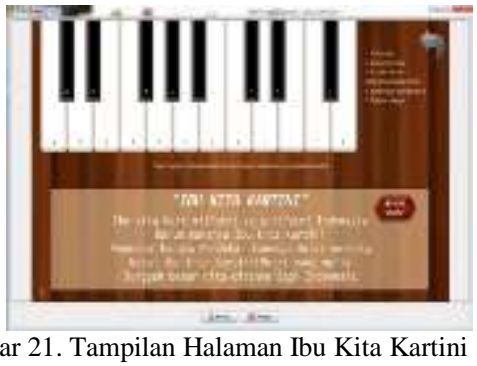

8. Tampilan Halaman Mengheningkan Cipta Gambar 22 menunjukkan tampilan halaman Mengheningkan Cipta.

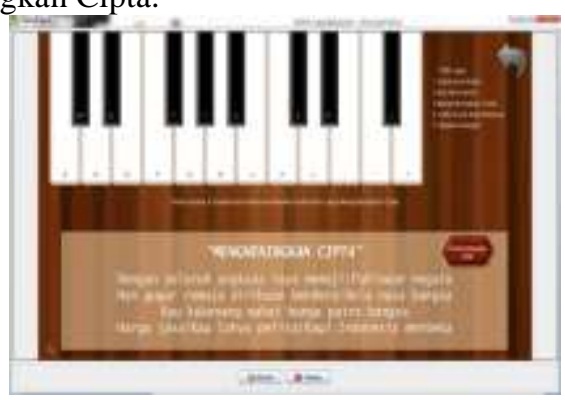

Gambar 22 Tampilan Halaman Mengheningkan Cipta

9. Tampilan Halaman Satu Nusa Satu Bangsa.

.Gambar 23 menunjukkan tampilan halaman Satu Nusa Satu Bangsa. Pada halaman Satu Nusa Satu Bangsa ini, terdapat terdapat lagu Satu Nusa Satu Bangsa yang dapat dimainkan dan dipelajari oleh pemain.

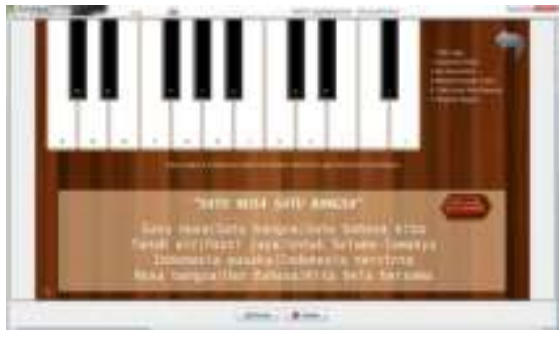

Gambar 23Tampilan Halaman Satu Nusa Satu Bangsa

\section{Tampilan Halaman Bagimu Negri}

Pada halaman Bagimu Negri ini, terdapat terdapat lagu Bagimu Negri yang dapat dimainkan dan dipelajari oleh pemain.Gambar 24 menunjukkan tampilan halaman Bagimu Negri.

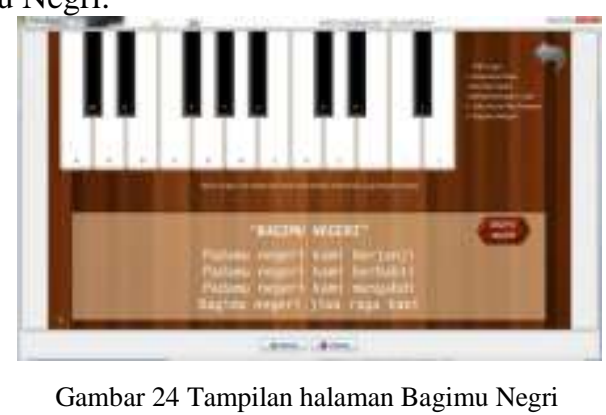

4. 2 Pengujian Media Pembelajaran Alat Musik Pianika

Hasil pengujian permainan menggunakan metode black-box, menunjukkan bahwa permainan sudah berjalan sesuai dengan spesifikasi kebutuhan dan skenario permainan. Hal ini tampak pada semua parameter yang menampilkan hasil uji "Berhasil" pada fungsi-fungsi dalam permainan dan "Benar" pada tombol dalam permainan. Secara fungsional, permainan ini sudah dapat menghasilkan keluaran yang diharapkan.

Berdasarkan hasil persentase yang diperoleh dari pengujian terhadap anak-anak usia 7-12 tahun, 95\% tertarik pada media pembelajaran alat musik pianika ini dan $95 \%$ menyukai tampilan media pembelajaran alat musik pianika. Media pembelajaran alat musik pianika ini juga mudah dioperasikan, sehingga anak-anak cepat beradaptasi dengan lingkungan media pembelajaran alat musik pianika. Hal ini ditunjukkan dengan persentase penilaian yang diperoleh, yaitu 92,5\%. Anak-anak juga memberikan penilaian sebesar 92,5\% untuk dapat memainkan permainan ini kembali. Setelah memainkan media pembelajaran alat musik pianika anak-anak menjadi lebih mudah belajar pianika dan menghafal lagu wajib. Hal ini ditunjukkan dengan persentase penilaian yang diperoleh, yaitu $92,5 \%$.

Seperti dalam batasan masalah, media pembelajaran alat musik pianika ini akan dijalankan pada sistem operasi Windows XP, Windows 7, dan Windows 8. Setelah dilakukan pengujian, permainan ini berjalan dengan baik pada Windows XP, dengan tampilan yang sama persis saat dijalankan pada Windows 7.

Media pembelajaran alat musik pianika ini sudah dijadikan berkas *.jar, sehingga apabila komputer atau notebook yang akan digunakan untuk menjalankan 
permainan belum mempunyai JDK, maka diharuskan untuk menginstalasinya terlebih dahulu. Versi minimal dari JDK yang harus dipenuhi yaitu 1.5. Ukuran dari permainan ini tidak terlalu besar, yaitu 29,5 MB, sehingga tidak akan terlalu menyita ruang pada harddisk.

\section{KESIMPULAN}

Kesimpulan dari penelitian ini adalah

1. Media pembelajaran alat musik pianika dapat berjalan dengan baik pada sistem operasi Windows XP dan Windows 7.

2. Tombol-tombol dan fungsi-fungsi yang terdapat pada media pembelajaran alat musik pianika dapat berfungsi dengan baik dan sesuai dengan fungsionalitasnya masingmasing.

3.Berdasarkan pengujian kepada 20 anak, semuanya menilai bahwa media pembelajaran alat musik pianika ini menarik. Hal ini dibuktikan dengan persentase penilaian yang diperoleh yaitu $95 \%$.

4.Tampilan media pembelajaran alat musik pianika dinilai bagus dan sesuai dengan tema. Hal ini dibuktikan dengan persentase penilaian yang diperoleh yaitu $95 \%$.

5.Media pembelajaran alat musik pianika ini mudah dipahami dan dioperasikan, sehingga anak-anak cepat beradaptasi dengan lingkungan media pembelajaran alat musik pianika. Hal ini ditunjukkan dengan persentase penilaian yang diperoleh, yaitu $92,5 \%$.

6.Anak-anak juga memberikan penilaian sebesar 92,5\% untuk dapat memainkan media pembelajaran alat musik pianika ini kembali, karena media pembelajaran alat musik ini mudah dipahami dan dioperasikan, serta tampilan gambar media pembelajaran alat musik pianika yang menarik dan anak-anak lebih mudah belajar pianika dan menghafal lagu wajib.

\section{SARAN}

1. Sebaiknya media pembelajaran alat musik pianika ini dibuat installer dalam bentuk *.exe, sehingga tidak membutuhkan proses instalasi pada komputer.

2. Pada media pembelajaran alat musik pianika ini masih terbatas menggunakan nada 2c sampai dengan 3g, sebaiknya ditambahkan beberapa oktaf nada lagi untuk penyempurnaan buyi ketika alat musik pianika dimainkan..

\section{DAFTAR PUSTAKA}

[1]. Sadiman, Arif.S., 2000, Aplikasi Teknologi dalam Pendidikan di Era Global, Jurnal Dikbud No.022.

[2]. Haryanto, S, Rosa A., M. Shalahuddin, 2000, Seri Pustaka Teknologi Pendidikan No.6, Penerbit CV.Rajawali, Jakarta.

[3]. James Au, Wagner, 2012, Game Design Secrers, Wiley.

[4]. Kolling , Michael, 2009, Introduction to Programming with Greenfoot Object-Oriented Programming in Java with Games and Simulations, Pearson Education.

[5]. Kurniasari, Yessy, R.Rizal.I, Oky D.N., 2013, Perancangan Permainan Mengasah Daya Ingat"Memory Training" Menggunakkan Greenfoot, Jurnal Sistem Komputer volume 1 Nomor 4 Tahun 2013.

[6]. Raharjo, Budi, 2012, Mudah Belajar Java, Penerbit INFORMATIKA, Bandung.

[7]. S, Rosa A. dan M, Shalahuddin, 2010, Modul Pembelajaran Pemrograman Berorientasi Objek, Penerbit Modula, Bandung.

[8]. S, Rosa A. dan M, Shalahuddin, 2013, Rekayasa Perangkat Lunak Terstruktur dan Berorientasi Objek, Penerbit INFORMATIKA, Bandung.

[9]. Sardiman, 2005, Interaksi dan Motivasi Belajar Mengajar, Penerbit Rajawali Press, Jakarta.

[10]. Shalahudin, M. dan Rosa A.S., 2008, Analisa dan Desain Sistem Informasi, Politeknik Negeri Telkom. 
